\title{
Desain Dan Pembuatan Dapur/Tungku Pemanas Untuk Kerajinan Pandai Besi Untuk Meningkatkan Kualitas Produk
}

\author{
Rusadi $^{1)}$, Hadimi ${ }^{2)}$, dan Edi Karyadi ${ }^{3)}$ \\ 1,2,3) Kelompok Penelitian Teknik Mesin \\ Jurusan Teknik Mesin, Politeknik Negeri Pontianak. \\ email: ${ }^{1)}$ rus4di@gmail.com, ${ }^{2)}$ had_imi@yahoo.co.id, ${ }^{3)}$ dik4ry4di@gmail.com
}

\begin{abstract}
Abstrak- Bisnis kerajinan besi adalah salah satu bisnis yang dapat berkembang seiring dengan perkembangan pertanian dan perkebunan. Namun perkembangannya mengalami kendala karena penggunaan teknologi manufaktur yang bersifat turun temurun sehingga kualitas produk yang dihasilkan menjadi rendah dan tidak mampu bersaing dengan produk luar. Produk kerajinan besi dalam bentuk alat pertanian dan perkebunan, sebenarnya dapat ditingkatkan kualitasnya dengan memperhatikan beberapa hal, yaitu bahan baku yang digunakan, pengaruh proses pembuatan dan pengerjaan serta proses pembuatan. Untuk alasan inilah peneliti dalam hal ini mencoba melakukan penelitian dalam bentuk tungku desain yang diharapkan dapat meningkatkan proses dan perlakuan panas sehingga menghasilkan peralatan pertanian dan produk perkebunan yang memiliki kualitas tinggi dalam hal ini sifat mekanik dan produksi yang berkualitas. biaya lebih murah.
\end{abstract}

Kata Kunci : kerajinan besi, tungku, perlakuan panas, kekerasan

\section{Pendahuluan}

Sektor pertanian dan perkebunan Kalimantan Barat berkembang dengan pesat karena arah kebijakan dari Pemprov dan potensi geografis yang mendukung. Prioritas pengembangan komoditi pertanian juga telah dilakukan hamper disemua wilayah Propinsi Kalimantan Barat seperti untuk komoditi padi, jagung, jeruk serta aloevera dengan luas total lahan pengembangan sebesar \pm 706.995 ha.

Jelas terlihat bahwa baik dari arah kebijakan Pemprov Kalimantan Barat sertapotensi dibidang pertanian dan perkebunan yang dimiliki akan mampu menggerakan roda pembangunan serta menciptakan peluang penyerapan tenaga kerja langsung yang cukupbesar.

Selain itu banyak peluang usaha yang dapat dilakukan untuk mendukung dan mampu berkembang seiring dengan pengembangan bidang pertanian dan perkebunan. Salah satu peluang usaha yang mungkin adalah bidang pengrajin besi atau pandai besi. Karena peluang usaha pandai besi ini menghasilkan alat-alat pendukung dan sangat dibutuhkan oleh bidang pertanian dan perkebunan seperti parang, cangkul, dodos, pisau sadap serta alat lainnya yang dibutuhkan.

Tetapi pada kenyataannya malah sebaliknya. Perkembangan usaha pandai besi di Kalimantan Barat malah sangat lambat atau bisa dikatakan mati suri. Dari hasil sebuah penelitian yang berhubungan dengan kualitas alat dodos lokal untuk sawit dikatakan bahwa alat pertanian produksi industri lokal masih belum bisa bersaing dengan produk import. Hal ini disebabkan karena kualitas produk masih rendah bila dibanding dengan produk import.Jika ditinjau dari segi harga produk import (Malaysia) sedikit lebih mahal bila dibanding dengan harga produk lokal, tetapi para pengusaha perkebunan sawit masih memilih produk buatan Import (Malaysia) karena kualitas produk lokal yang masih rendah sehingga para pengusaha mengalihkan penggunaan alat panen keproduk import. Hal ini mengakibatkan turunnya jumlah produksi dibeberapa perusahaan lokal pembuat alat pertanian dan perkebunan [1].

Dengan melihat latar belakang yang telah disebutkan di atas, maka dengan ini penulis tertarik untuk melakukan suatu penelitian yang diharapkan mampu meningkatkan mutu produk dari pandai besi khususnya produk yang berhubungan dengan alat pertanian dan perkebunan. Penelitian ini diarahkan untuk membuat proses pengerjaan alat pertanian dan perkebunan yang mampu menghasilkan mutu produk yang lebih baik dan bersaing dengan produk luar.

Salah satu upaya yang akan dilakukan adalah dengan cara mendesain tungku pembakaran yang lebih efisien dane fektif untuk mencapai temperature yang lebih ideal untuk menghasilkan tingkat kekerasan yang disyaratkan untuk sebuah alat pertanian dan perkebunan. Diharap kan juga dengan tungku ini terbuangnya energi untuk menghasilkan temperatur yang diinginkan, menjadi lebih rendah.

\section{Tinjauan Pustaka}

\subsection{Sifat Bahan}

Sejak zaman dahulu kala pandai besi mengetahui bahwa sifat bahan dapat dirubah melalui pemanasan yang disusul dengan pendinginan, mereka mengenal berbagai proses perlakuan panas meski tidak mengetahui dengan pasti apa yang terjadi dalam logam itu sendiri[4]. Ilmu dan Teknologi Bahan telah tumbuh dan berkembang menjadi satu bidang tersendiri selama 50 tahun terakhir ini. Pengembangan ini berintikan temuan tertentu yaitu konsep bahwa sifat dan kelakuan bahan berhubungan erat dengan struktur internal dari bahan tersebut [5]. Artinya agar sifat dapat diubahubah harus diadakan perubahan yang sesuai pada struktur 
internal bahan. Demikian pula bila pemerosesan atau keadaan pemakaian merubah struktur, karakteristik bahan akan berubah pula.

Ada beberapa hal yang bisa mempengaruhi struktur dari logam yang secara tidak langsung juga mempengaruhi sifat mekanis dari bahan yaitu:

\section{- Komposisi kimia dari bahan.}

Pada umumnya komposisi kimia dari bahan sangat mempengaruhi sifat fisis maupun mekanis. Khususnya untuk pembuatan alat-alat pertanian dan perkebunan yang dilakukan oleh pandai besi maka bahan yang sering dipakai adalah baja. Baja sangat dipengaruhi oleh komposisi kimia khususnya kadar karbon. Pada umumnya baja yang digunakan oleh pandai besi adalah baja dengan komposisi karbon sebesar $0,45 \%-0,50 \% \mathrm{C}$ yang tergolong ke dalam baja dengan kadar karbon sedang (AISI 1045).

- Pengaruh proses pembuatan, pengerjaan atau pabrikasi.

Proses pembuatan, pengerjaan atau pabrikasi juga sangat berpengaruh pada sifat mekanis dari sebuah produk. Akan mudah bagi kita untuk mendapatkan sifat mekanis yang diinginkan dari produk terutama produk hasil kerajinan pandai besi jika proses itu dapat kita setting sesuai dengan syarat yang dibutuhkan dalam menghasilkan sifat mekanis tertentu. Tetapi pada kenyataannya, banyak kerajinan pandai besi yang tidak dapat melakukan itu karena dapur yang digunakan masih bentuk dapur yang merupakan teknologi warisan jaman dahulu karena memang pekerjaan ini sifatnya turun temurun.

- Proses perlakuan panas.

Di dalam Ilmu dan Teknologi Bahan dikenal istilah Perlakuan Panas. Proses Perlakuan Panas didefinisikan sebagai proses memanaskan dan mendinginkan suatu bahan untuk mendapatkan perubahan fasa (struktur) guna meningkatkan kemampuan bahan tersebut sehingga bertambah daya guna tekniknya dengan mengatur struktur dan sifat mekanis bahan tersebut, seperti mengeraskan, melunakan, menghilangkan tegangan sisa, menaikan ketangguhan dan lain-lain.

\subsection{Jenis-Jenis Proses Perlakuan Panas}

Ada beberapa jenis proses perlakuan panas dan dapat dipakai dalam proses pembuatan alat pertanian dan perkebunan untuk mendapatkan hasil produk yang berkualitas yaitu:

\section{- Annealing}

Memanaskan suatu bahan hingga diatas suhu transformasi kemudian didinginkan dengan perlahan-lahan. Tujuannya adalah untuk melunakan bahan[3].

\section{- Stress Reliveing}

Yaitu proses menghilangkan tegangan sisa dari suatu bahan dengan memanaskan kemudian ditahan beberapa waktu lalu dilakukan dengan pendinginan perlahan- lahan. Tujuannya adalah untuk menghilangkan tegangan sisa selama proses fabrikasi.

\section{- Hardening}

Memanaskan suatu bahan hingga diatas suhu transformasi kemudian didinginkan secara cepat, melalui media pendingin seperti air, oli atau media pendingin lainnya. Tujuannya adalah untuk mengeraskan bahan.

- Aging (Precipitation Hardening).

Proses pemanasan kembali bahan yang telah dikeraskan. Suhu pemanasannya relatif rendah yaitu dibawah suhu transformasi eutektoid. Tujuannya adalah untuk mengurangi kekerasan bahan sehingga keuletan (ketangguhan) bahan tersebut dapat naik.

\section{Metodologi Peneltian}

Metode penelitian yang digunakan sebagai berikut :

\section{Pengumpulan Data Awal}

Pengumpulan data dilakukan pada beberapa pengrajin pandai besi untuk beberapa wilayah terutama yang berada di Kodya Pontianak maupun yang ada di Kabupaten Kubu Raya. Pengumpulan data awal yang akan diambil adalah berupa:

- Kondisi kerja, teknik kerja dan lingkungan dari tempat pandai besi melakukan pekerjaan

- Bentuk tungku yang digunakan

- Bahan bakar yang digunakan termasuk kepadatannya dan jumlahnya untuk pembakaran

- Material yang digunakan untuk produk

- Temperatur pembakaran

- Tingkat kekerasan dari produk

2. Penentuan Paramameter untuk mendukung Penelitian

Parameter yang digunakan untuk penelitian adalah parameter yang bisa mempengaruhi sifat mekanis dari produk yang dihasilkan yaitu:

- Komposisi kimia dari bahan

- Temperatur dari proses

- Tingkat kekerasan produk.

\section{Desain Dapur Untuk Pandai Besi}

Pada tahap ini akan dibuat desain dari dapur yang akan digunakan oleh pandai besi dalam menghasilkan produk berupa alat pertanian dan perkebunan. Desain dilakukan dengan berdasarkan data awal yang didapat dari beberapa pengrajin pandai besi di wilayah Kodya Pontianak dan Kabupaten Kubu Raya. Hasil desain tadi kemudian dibuatlah dapur yang akan ditempatkan disalah satu tempat pandai besi saat pengambilan data awal.

\section{Pengujian dan Pengumpulan Data Penelitian}

Tahap ini adalah pengujian dapur yang dibuat. Pengujian proses dilakukan langsung di tempat dimana dapur hasil desain berada. Sedangkan pengujian kekerasan produk dilakukan di Laboratorium Teknik Mesin Jurusan Teknik Mesin Politeknik Negeri Pontianak. Waktu penelitian 8 bulan. 


\section{Analisis Data}

Dari data-data hasil pengujian diatas dijadikan acuan untuk menentukan apakah hasil desain dapur yang dibuat sudah bisa digunakan untuk menghasilkan produk alat pertanian dan perkebunan sehingga dapat dijadikan acuan oleh usaha pengrajin pandai besi yang lainnya.

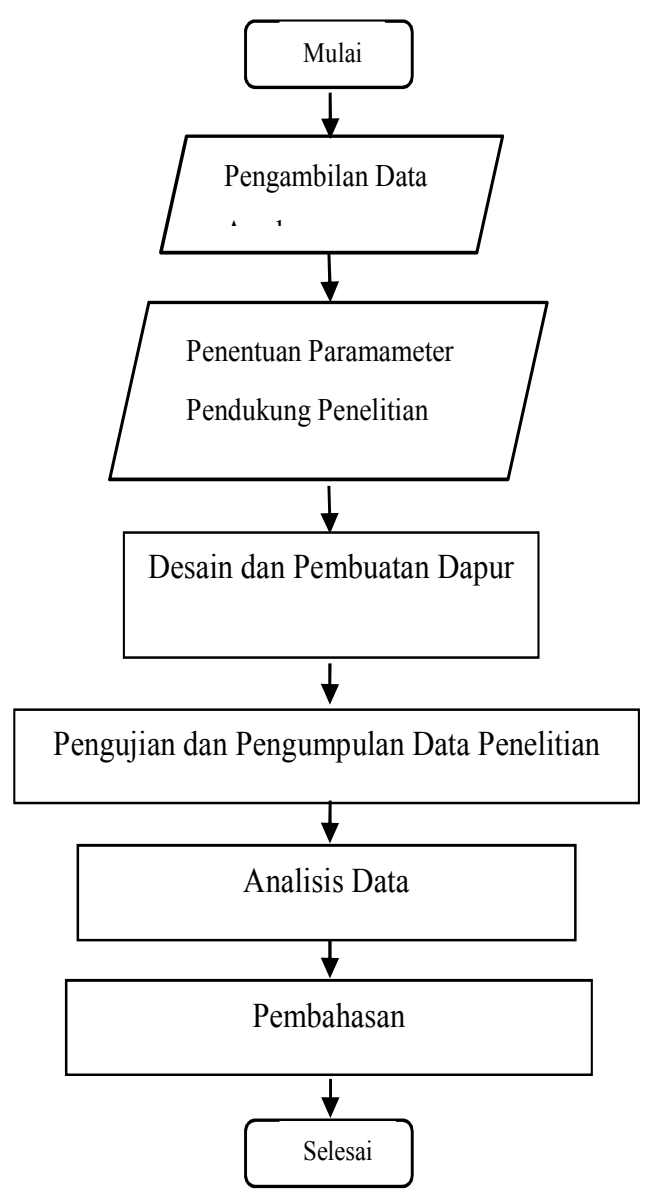

Gambar 1. Diagram alur penelitian

\section{Hasil Dan Pembahasan}

\subsection{Pertimbangan dan Desain Tungku Pemanas}

Dari beberapa pengrajin pandai besi yang telah kita amati yaitu di Desa Parit Gadoh dan Desa Punggur Besar di Kabupaten Kubu Raya serta Desa Jungkat di Kabupaten Mempawah dapat diambil data awal sebagai berikut:

- Rata-rata pengrajin masih menggunakan dapur tradisional dengan bahan bakar arang kayu dan dilengkapi blower untuk penghembus udaranya

- Bahan yang digunakan dalam proses pembuatan alat pertanian dan perkebunan tidak seragam tergantung kepada bahan baja yang tersedia, tapi kebanyakan menggunakan baja pegas atau mereka menyebutnya "spring"

- Dilakukan proses pembentukan dengan pemukulan menggunakan martil
- Pendinginan dilakukan dengan cara mencelupkan ke dalam air.

Dengan pertimbangan kondisi proses pembuatan produk alat pertanian dan perkebunan yang dilakukan oleh pandai besi tradisional diatas maka peneliti mendesain sebuah tungku dengan kriteria sebagai berikut:

- Tungku ini dibuat lebih simpel sehingga mudah dalam proses pembuatan dan pengoperasiannya

- Bahan bakar yang digunakan adalah gas dengan dinding tungku terbuat dari plat $4 \mathrm{~mm}$ dan isolasi panas menggunakan glass wool di sekeliling dinding dalam

- Tungku pemanas dilengkapi dengan blower yang bisa diatur kecepatan udaranya yang nantinya digunakan untuk menyuplai udara pembakaran dan mengatur temperatur dari tungku

- Tungku dilengkapi dengan cerobong.

\subsection{Pengujian Tungku Pemanas Hasil Desain}

Tungku pemanas yang dibuat dan diuji di Laboratorium Teknik Mesin Politeknik Negeri Pontianak. Dari hasil pengujian yang dilakukan maksimal temperatur yang dicapai adalah sebesar $900^{\circ} \mathrm{C}$.

Adapun gambar tungku hasil desain dari penelitian ini dapat dilihat pada gambar berikut ini:

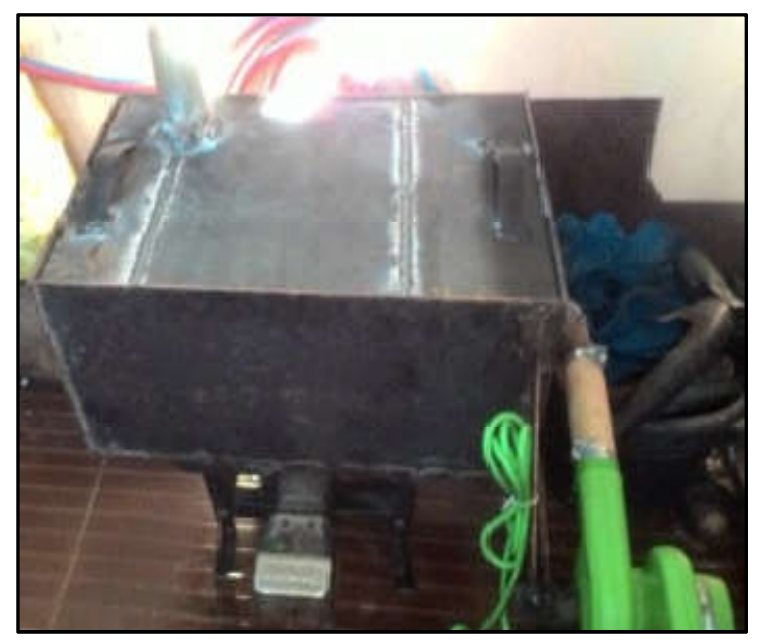

Gambar 2. Tungku Pemanas Hasil Desain 


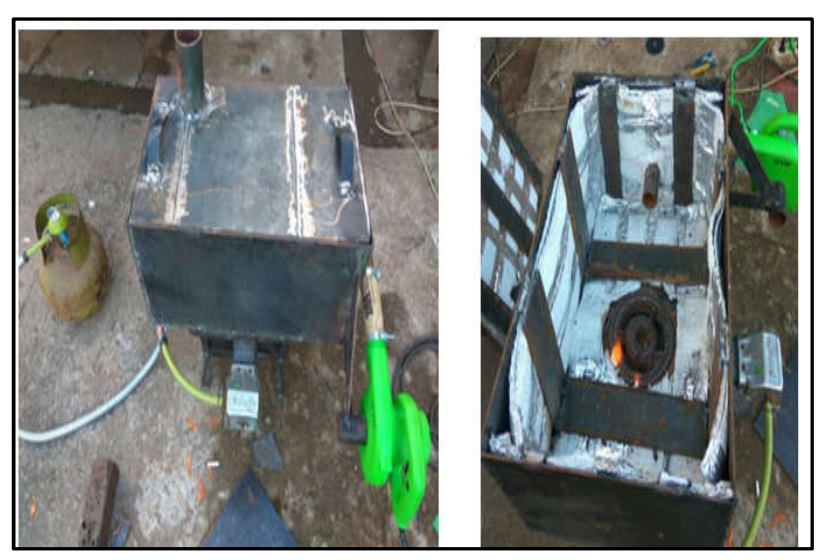

Gambar 3. Percobaan Tungku Pemanas Hasil Desain

4.3. Data Percobaan Proses Heat Treatment Menggunakan Tungku Pemanas

Dengan menggunakan tungku pemanas yang dibuat, peneliti melakukan beberapa percobaan pemanasan produk alat pertanian dari beberapa pengrajin besi yang kita ambil sebagai obyek survey awal. Produk alat pertanian yang diambil adalah parang, kapak dan cangkul. Data kekerasan sebelum dan sesudah dilakukan pemanasan dengan menggunakan tungku pemanas adalah sebagai berikut:

Tabel 1. Kenaikan kekerasan alat pertanian hasil pandai besi setelah dipanaskan menggunakan dapur hasil desain

\begin{tabular}{|c|c|c|c|c|c|}
\hline \multirow[b]{2}{*}{ No. } & \multirow[b]{2}{*}{ Tempat Pengrajin } & \multirow[b]{2}{*}{ Nama Alat } & \multicolumn{2}{|c|}{ Tinglkat Kekerassan (HRC) } & \multirow{2}{*}{$\begin{array}{l}\text { Kenaikan Kekerasan } \\
\text { (HRC) }\end{array}$} \\
\hline & & & Sebelum & Setelah & \\
\hline \multirow[t]{3}{*}{1.} & Desa Parit Gadoh & Kapak & 42 & 51 & 9 \\
\hline & & Parang & 39 & 61 & 22 \\
\hline & & Cangkul & 39 & 58 & 19 \\
\hline \multirow[t]{3}{*}{2.} & Desa Punggur Besar & Kapak & 35 & 42 & 7 \\
\hline & & Parang & 35 & 49 & 14 \\
\hline & & Cangkul & 35 & 49 & 14 \\
\hline \multirow[t]{4}{*}{ 3. } & Desa Jungkat & Kapak & 41 & 58 & 17 \\
\hline & & Parang & 38 & 59 & 21 \\
\hline & & Cangkul & 38 & 59 & 21 \\
\hline & Nilai Rata-Rata & Kekerasan & 38 & 54 & 16 \\
\hline
\end{tabular}

Berdasarkan data hasil percobaan yang dilakukan yaitu proses pemanasan dengan menggunakan tungku pemanas hasil desain untuk produk alat pertanian dan perkebunan yang dihasilkan pandai besi terdapat kenaikan kekerasan. Adapun kenaikan kekerasan itu dapat dilihat pada tabel 2 berikut ini.
Tabel 2. Kenaikan Kekerasan Dari Alat Hasil Pandai Besi

\begin{tabular}{|c|c|c|c|c|c|}
\hline \multirow{2}{*}{ No. } & \multirow{2}{*}{ Tempat Pengrajin } & \multirow{2}{*}{ Nama Alat } & \multicolumn{2}{|c|}{$\begin{array}{l}\text { Tingkat Kekerasan } \\
\text { (HRC) }\end{array}$} & \multirow{2}{*}{$\begin{array}{c}\text { Kenaikan } \\
\text { Kekerasan } \\
\text { (HRC) }\end{array}$} \\
\hline & & & Sebelum & Setelah & \\
\hline \multirow[t]{3}{*}{1.} & Desa ParitGadoh & Kapak & 42 & 51 & 9 \\
\hline & & Parang & 39 & 61 & 22 \\
\hline & & Cangkul & 39 & 58 & 19 \\
\hline \multirow[t]{3}{*}{2.} & Desa Punggur Besar & Kapak & 35 & 42 & 7 \\
\hline & & Parang & 35 & 49 & 14 \\
\hline & & Cangkul & 35 & 49 & 14 \\
\hline \multirow[t]{4}{*}{3.} & Desa Jungkat & Kapak & 41 & 58 & 17 \\
\hline & & Parang & 38 & 59 & 21 \\
\hline & & Cangkul & 38 & 59 & 21 \\
\hline & \multicolumn{2}{|c|}{ Nilai Rata-Rata Kekerasan } & 38 & 54 & 16 \\
\hline
\end{tabular}

Tingkat kekerasan dari dari produk alat pertanian dan perkebunan yang dihasilkan pandai besi setelah dilakukan proses pemanasan lanjut pada tungku pemanas mengalami kenaikan rata-rata $16 \mathrm{HRC}$.

Dari beberapa produk alat pertanian dan perkebunan yang dilakukan percobaan kenaikan terkecil terjadi pada kapak. Hal ini kemungkinan disebabkan oleh ketebalan dari alat tersebut. Sedangkan 2 alat lainnya yang dijadikan sampel yaitu parang dan cangkul, kenaikan relatif sama.

\section{KESIMPULAN}

Berdasarkan hasil penelitian dan pembahasan di atas dapat disimpulkan bahwa:

- Tungku pemanas hasil desain mampu mencapai temperatur $900^{\circ} \mathrm{C}$ dimana bahan bakar yang digunakan adalah LPG

- Penggunaan blower dalam desain tungku pemanas ini dapat menjaga tingkat temperatur sehingga dalam proses pemanasan atau heat treatment, holding time bisa dilakukan

- Heat Treatment yang dilakukan dengan menggunakan tungku pemanas ini mampu menaikkan tingkat kekerasan dari produk alat pertanian dan perkebunan yang dihasilkan pandai besi dengan rata-rata kenaikan $16 \mathrm{HRC}$. 


\section{DAfTAR PUSTaka}

[1] Suherman, Syakura,A \& Mizhar, Susri, 2012 "Perbaikan Sifat Fisis dan Mekanis Alat Panen Buah Kelapa Sawit (Egrekdan Dodos) Produk Lokal", Jurnal Dinamis Voll 11 Juni 2012

[2] Sriwardhanu, Nyeyep, 2014"Heat Treatment Process", Sebelas Maret Univesity Holman,J.P, 1986 “Heat Transfer”, McGraw Hill Book Company, 6th edition

[3] Surojo, Eko, Dodi Ariawan, Nurchozin, M, 2009 “Pengaruh Manual Flame Hardening Terhadap Kekerasan Hasil Tempa Baja Pegas” Jurnal Mekanika Vol.7 No. 2 Maret 2009

[4] Van Vlackm Lauren H, alih Bahasa Japrie, Sriyati, 1995 "Ilmu dan Teknologi Bahan" : Erlangga Jakarta

[5] Tri Wahyudi, Silvia Uslianti, 2016 “ Peningkatan Kualitas dan Kuantitas Nugget Lele dengan Menggunakan Mesin Mekanis “Jurnal ELKHA Vol.8, No 2, Oktober 2016.

[6] Salam, Arkawira Nul, Bayuseno, Athanasius Priharyoto, 2016, "Pengaruh Penambahan Unsur Silikon Material Model Shaft Propeller Berbahan Dasar AL6063 Terhadap Sifat Fisis Dan Mekaniks Hasil Pengecoran HPDC" Jurnal Teknik Mesin Vol 4, No 2 (2016): Vol 4, No 2, April 2016. 